\title{
PENGARUH REKLAMASI LAHAN RAWA TERHADAP PENURUNAN PRODUKSI DAN PERUBAHAN KOMPOSISI JENIS IKAN PADA USAHA PERIKANAN BEJE DI KABUPATEN KAPUAS, KALIMANTAN TENGAH
}

\author{
Endi Setiadi Kartamihardja")
}

\begin{abstract}
ABSTRAK
Beje adalah kolam yang dibuat di daerah rawa banjiran dan berfungsi sebagai tempat penangkapan ikan. Perikanan beje merupakan usaha perikanan utama bagi masyarakat nelayan di Kabupaten Kapuas, Kalimantan Tengah. Penelitian ini ditujukan untuk mengetahui pengaruh reklamasi lahan rawa terhadap produksi dan komposisi jenis ikan pada usaha perikanan beje di Kabupaten Kapuas setelah empat tahun Proyek Pembukaan Lahan Gambut (PLG) dilaksanakan. Produksi dan komposisi jenis ikan diamati berdasarkan data hasil tangkapan di 70 buah sampel beje sebelum dan sesudah reklamasi lahan rawa dilaksanakan. Hasil penelitian menunjukkan bahwa produksi ikan di beje menurun sangat tajam dari kisaran 500-2000 kg/beje/th (sebelum lahan rawa direklamasi 1996) menjadi 5-150 kg/beje/th (setelah lahan rawa direklamasi) atau menurun sebesar $94,6 \%$. Penurunan produksi tersebut terutama disebabkan oleh perubahan fluktuasi air sebagai akibat pembuatan saluran irigasi, dan kerusakan habitat ikan rawa. Komposisi jenis ikan yang dominan tertangkap di beje berubah dari gabus (Channa striata) pada waktu sebelum reklamasi menjadi pepuyu (Anabas testudineus) setelah reklamasi. Ukuran ikan gabus dan sepat yang tertangkap menurun, masing-masing dari kisaran 500-2500 g/ekor dan 50-150 g/ekor pada waktu sebelum reklamasi menjadi 50-200 g/ekor dan 25-75 g/ekor setelah reklamasi. Untuk menggantikan usaha perikanan beje dan pelestarian sumber daya ikan perlu dikembangkan usaha budi daya ikan di kolam pasang surut, pengembangan suaka perikanan dan alternatif pengelolaannya. Jenis ikan budi daya yang dikembangkan adalah jenis-jenis ikan asli (indigenous species) seperti pepuyu (Anabas testunideus) dan biawan (Helostoma temminckii) serta ikan baung (Mystus nemurus) dan patin (Pangasius djambal) yang teknologi pembenihannya sudah dikuasai.
\end{abstract}

ABSTRACT: The effect of reclamation of swamp areas on fish production and composition from "beje" fishery in Kapuas Regency, Central Kalimantan. By: Endi Setiadi Kartamihardja

"Beje", is a pond constructed in swamp areas for collecting and catching fish. Beje fishery is the main fishing activity in the open waters of Kapuas, Central Kalimantan. The purpose of this study is to investigate the effect of reclamation of swamp areas on the fish yield and fish composition from "beje" fishery in Kapuas, four years after the reclamation of the area. Fish production and composition were estimated using fish harvests collected from 70 "beje" samples in 1996 (before reclamation) and in 2000 (after reclamation). The results demonstrated that fish production from "beje" decreased significantly from 500-2000 kg of fish/"beje"/year in 1996 to 5-150 kg/"beje"/year in 2000, which is about $94.6 \%$. The main cause of the decline in fish yield was due to the change in the fluctuation of the water level affected by canal construction and deterioration of black fishes habitat. The dominant species had changed from snakehead (Canna striata) to climbing perch (Anabas testudineus). The weight of snakehead and climbing perch also decreased from $500-2,500 \mathrm{~g}$ and $50-150 \mathrm{~g}$ (before reclamation) to $50-200 \mathrm{~g}$ and $25-75 \mathrm{~g}$ (after reclamation), respectively. To revive the "beje" fisheries and to sustain the fisheries resources, it is required to develop fish farming activities of some indigenous species, to create fisheries reserves and to provide better management of fisheries resources

KEYWORDS: "beje" fishery, fish productivity, swamp areas, black fishes, pond aquaculture, reclamation

\section{PENDAHULUAN}

Proyek Pembukaan Lahan Gambut (PLG) di Kalimantan Tengah mulai dikerjakan pada tahun 1996 dengan cara mereklamasi lahan rawa menjadi lahan pertanian terutama lahan persawahan. Lahan rawa dan dataran banjirnya (flood plain area) merupakan salah satu tipe perairan umum di mana

\footnotetext{
"Peneliti pada Pusat Riset Perikanan Tangkap, Jakarta
}

lahan tersebut juga berfungsi sebagai habitat ikan rawa (black fishes) (Welcome, 1985). Perairan umum di Kalimantan yang luasnya mencapai 8 juta ha mempunyai kekayaan jenis ikan tidak kurang dari 394 jenis yang sebagian besar termasuk ke dalam ordo Ostariophysi dan Labyrinthici (Kottelat et al., 1993). Di perairan Kalimantan Tengah, diperkirakan terdapat tidak kurang dari 100 jenis ikan yang 
didominasi oleh gabus (Channa spp), sepat (Trichogaster spp), jelawat (Leptobarbus hoeveni), kelabau (Osteochilus spp), pipih (Notopterus spp), patin (Pangasius spp), betutu (Oxyeleotris marmorata), pepuyu (Anabas testudineus), dan baung (Mystus nemurus) (Hamid, 1982).

Lahan rawa dan dataran banjir yang terletak di Kabupaten Kapuas, khususnya di desa Dadahup dan Terantang digunakan oleh masyarakat setempat sebagai lahan usaha perikanan beje. Beje adalah kolam berbentuk persegi panjang yang dibuat di perairan rawa banjiran dan berfungsi untuk mengumpulkan dan menangkap ikan. Antara beje dengan aliran sungai atau dengan beje lainnya dihubungkan dengan parit yang dalam bahasa daerah disebut "tatah" atau "pelacar". Pada musim hujan, permukaan air sungai akan naik dan menggenangi rawa dan beje di sekitarnya. Sedangkan pada musim kemarau saat permukaan air sungai surut, perairan rawa juga surut, dan saluran penghubung kering sebagai akibatnya air dalam beje terisolir. Pada waktu tersebut ikan akan terkumpul dalam beje sehingga dengan mudah dapat ditangkap. Usaha perikanan beje di Kabupaten Kapuas sudah berjalan sejak tahun 1950.

Sebelum reklamasi lahan rawa dilaksanakan pada tahun 1996, di Desa Dadahup dan Terantang terdapat sebanyak 1900 beje. Sedangkan setelah reklamasi lahan rawa dilaksanakan, sebagian besar lahan rawa kering, sebagai akibatnya luas habitat ikan berkurang begitu pula sebagian besar beje dan tatah kering. Di Desa Dadahup sebanyak 1.739 beje dan di desa Terantang, Lamunti sebanyak 100 beje kekeringan dan sudah tidak berfungsi lagi (Kartamihardja et al., 1998). Keadaan tersebut diduga akan berdampak lanjutan terhadap menurunnya hasil tangkapan ikan, hilangnya mata pencaharian, dan pendapatan nelayan serta kemungkinan menurunnya keanekaragaman jenis ikan (species biodiversity)

Penelitian ini ditujukan untuk mengetahui pengaruh pembukaan lahan gambut (reklamasi lahan rawa) terhadap produksi (hasil tangkapan ikan), komposisi jenis, dan ukuran ikan pada usaha perikanan beje di Kabupaten Kapuas, Kalimantan Tengah.

\section{BAHAN DAN METODE}

Lokasi penelitian dipusatkan di beje milik masyarakat yang terletak di perairan rawa sekitar Proyek Pembukaan Lahan Gambut (PLG) di desa Dadahup, Telekung Punai, Tambak Bajai, dan Terantang, Kabupaten Kapuas. Penelitian dilakukan pada bulan Juni, Agustus, dan Oktober tahun 1996 dan 2000.
Jumlah total beje yang terdapat di desa Dadahup, Telekung Punai, Tambak Bajai, dan Terantang sebelum Proyek PLG dilaksanakan (sebelum tahun 1996) diperkirakan sebanyak 1900 unit. Sedangkan empat tahun sesudah reklamasi lahan rawa yakni pada tahun 2000 terdapat sekitar 100 unit beje yang masih berfungsi. Dari 100 unit beje tersebut dipilih secara acak sebanyak 70 unit sebagai sampel yang terdiri dari 33 unit di desa Dadahup, 32 unit di Telekung Punai, dan 5 unit di Tambak Bajai

Produksi, komposisi jenis, dan ukuran ikan dihitung dari hasil pengamatan 70 buah sampel beje baik sebelum maupun empat tahun setelah proyek pembukaan lahan gambut dilaksanakan. Parameter yang diamati adalah kepadatan stok, bobot/biomassa, komposisi jenis, dan ukuran panjang ikan serta ukuran beje. Produksi ikan untuk setiap beje dinyatakan dalam $\mathrm{kg}$ ikan/beje/th yang dihitung berdasarkan data hasil tangkapan ikan di 70 unit sampel beje yang diteliti.

Sebagai data penunjang yaitu data fluktuasi permukaan air musiman diambil melalui wawancara dengan masyarakat nelayan setempat dan sebagai acuan digunakan data fluktuasi air seperti yang dikemukakan Kartamihardja (2000).

Untuk mengetahui pengaruh reklamasi lahan rawa terhadap perikanan beje dilakukan dengan cara menganalisis dan membandingkan data produksi (hasil tangkapan), komposisi, dan ukuran jenis ikan yang tertangkap di sampel beje sebelum dan sesudah reklamasi lahan rawa dilaksanakan. Data tersebut disajikan dalam bentuk tabel, kemudian dianalisis secara deskriptif.

\section{HASIL DAN BAHASAN}

\section{Produksi lkan}

Sampel beje yang diteliti mempunyai ukuran panjang antara 15-25 $\mathrm{m}$, lebar 2-3 $\mathrm{m}$, dan kedalaman 2,0-2,5 m. Antara beje dengan aliran sungai atau dengan beje lainnya dihubungkan dengan parit yang lebarnya antara 1-2 $\mathrm{m}$ dan kedalaman 0,5-1 m.

Produksi ikan yang dihitung dari 70 buah sample beje sebelum proyek PLG dilaksanakan dan empat tahun setelah dilaksanakan (selama musim panen tahun 2000) tertera pada Tabel 1.

Sebelum reklamasi lahan rawa dilaksanakan, produksi ikan dari beje cukup tinggi yakni berkisar antara 500-2000 kg/beje/tahun atau rata-rata $1190 \pm 35 \mathrm{~kg} / \mathrm{beje} / \mathrm{th}$, di mana sebagian besar beje 
Tabel 1. Produksi beje $(\mathrm{kg} \mathrm{ikan} / \mathrm{beje} / \mathrm{th})$ sebelum dan sesudah reklamasi lahan rawa di Kabupaten Kapuas

Table 1. Yield of "Beje" ( $\mathrm{kg}$ of fish/beje/yr) before and after reclamation of swampy areas at Kapuas Regency

Sebelum reklamasi th 1996

(Before reclamation in 1996)
Setelah reklamasi th $2000 /$

(After reclamation in 2000)

\begin{tabular}{cccccccc}
\hline \multicolumn{2}{c}{$\begin{array}{c}\text { Sampel Beje } \\
\text { ("Beje" sample) }\end{array}$} & \multicolumn{2}{c}{$\begin{array}{c}\text { Produksi Beje } \\
\text { (Yield of "Beje") }\end{array}$} & \multicolumn{2}{c}{$\begin{array}{c}\text { Sampel Beje } \\
\text { ("Beje" sample) }\end{array}$} & \multicolumn{2}{c}{$\begin{array}{c}\text { Produksi Beje } \\
\text { (Yield of "Beje") }\end{array}$} \\
\hline N & $(\%)$ & $\begin{array}{c}\text { Kisaran/ } \\
\text { (Range) }\end{array}$ & $\begin{array}{c}\text { Rata-ratal } \\
\text { (Average) }\end{array}$ & $\mathbf{N}$ & $\mathbf{( \% )}$ & $\begin{array}{c}\text { Kisaran/ } \\
\text { (Range) }\end{array}$ & $\begin{array}{c}\text { Rata-rata/ } \\
\text { (Average) }\end{array}$ \\
\hline 39 & 55,7 & $500-1000$ & $650 \pm 45$ & 50 & 71,4 & $5-50$ & $18 \pm 3$ \\
23 & 32,9 & $1100-1500$ & $1240 \pm 30$ & 16 & 22,9 & $55-100$ & $62 \pm 6$ \\
8 & 11,4 & $1600-2000$ & $1680 \pm 55$ & 4 & 5,7 & $105-150$ & $112 \pm 6$ \\
\hline 70 & 100 & $\mathbf{5 0 0 - 2 0 0 0}$ & $\mathbf{1 1 9 0} \pm \mathbf{3 5}$ & $\mathbf{7 0}$ & $\mathbf{1 0 0}$ & $\mathbf{5 - 1 5 0}$ & $\mathbf{6 4} \pm \mathbf{5}$ \\
\hline
\end{tabular}

$(55,7 \%)$ produksinya berkisar antara 500-1000 $\mathrm{kg} / \mathrm{beje} / \mathrm{th}$ dengan rata-rata $650 \pm 45 \mathrm{~kg} / \mathrm{beje} / \mathrm{th}$. Empat tahun setelah reklamasi produksi ikan dari beje tersebut menurun sangat tajam menjadi 5-150 $\mathrm{kg} / \mathrm{beje} / \mathrm{th}$ atau rata-rata $64 \pm 5 \mathrm{~kg} / \mathrm{beje} / \mathrm{th}$, di mana sebagian besar beje $(71,4 \%)$, produksinya hanya 5$50 \mathrm{~kg} / \mathrm{beje} / \mathrm{th}$ dengan rata-rata $18 \pm 3 \mathrm{~kg} / \mathrm{beje} / \mathrm{th}$. Dengan demikian, reklamasi lahan rawa telah berdampak negatif terhadap produksi ikan pada perikanan beje rata-rata sebesar $94,6 \%$.

Produksi ikan yang menurun sangat tajam tersebut diduga berkaitan erat dengan perubahan pola fluktuasi air. Pembuatan saluran irigasi yang menghubungkan Sungai Barito, Kapuas, dan Mengantip telah merubah pola fluktuasi air. Sebelum reklamasi lahan rawa dilaksanakan, pada musim hujan permukaan air sungai akan meluap sehingga daerah rawa banjiran akan tergenang dengan ketinggian air mencapai 2 m (Kartamihardja, 2000). Setelah reklamasi lahan rawa, permukaan air sungai tidak meluap menggenangi daerah rawa banjiran lagi sehingga sebagian besar daerah rawa tetap kering dan sebagai akibatnya habitat ikan rawa menjadi rusak. Di samping itu, penggalian saluran irigasi telah pula membongkar lapisan gambut sehingga $\mathrm{pH}$ perairan turun menjadi 4,0-4,5 dan terjadi oksidasi dan menghasilkan pirit $\left(\mathrm{Fe}_{2} \mathrm{~S}_{3}\right)$ yang bersifat racun terhadap ikan. Pembukaan lahan rawa juga membabat hutan rawang yang ada. Padahal ditinjau dari aspek limnologinya, Kartamihardja (2000) menyatakan bahwa perairan rawa yang paling layak untuk pengembangan beje adalah perairan rawa banjiran dengan indek peringkat kualitas air 36,2 ; $\mathrm{pH}$ perairan antara 5-6,5; ditumbuhi hutan rawang, pohon gelam (Eugenia spp), rumput kumpai (Graminae), purun (Fimbristylis spp), parupuk dan kayu duri (Mymosa nigra) serta pada musim hujan daerah tersebut mendapat limpahan air dari sungai sekitarnya. Dengan demikian, kondisi habitat rawa yang sesuai untuk pengembangan beje sudah tidak terdapat lagi

\section{Komposisi Jenis Ikan}

Jenis-jenis ikan yang menghuni perairan umum di sekitar lahan rawa bukaan di Kabupaten Kapuas, Kalimantan Tengah diketahui sebanyak 35 jenis (Kartamihardja, 2000; Sarnita, 1998), namun jenis ikan yang umumnya tertangkap di beje hanya 6 jenis yang semuanya termasuk ikan rawa, yaitu ikan haruan atau gabus (Channa striata), pepuyu, biawan (Helostoma temminckii), sepat (Trichogaster trichopterus), kapar (Pristolepis fasciatus), dan pentet (Clarias spp). Komposisi jenis ikan yang tertangkap di beje sebelum dan sesudah reklamasi lahan rawa mengalami perubahan (Tabel 2).

Sesudah reklamasi dilaksanakan, komposisi ikan gabus dan pepuyu yang tertangkap berubah sangat nyata sedangkan jenis ikan lainnya berubah tidak nyata. Sebelum reklamasi lahan rawa dilaksanakan, ikan gabus dan pepuyu yang merupakan jenis ikan utama, masing-masing dengan komposisi rata-rata $51,5 \pm 2,6 \%$ dan $25,6 \pm 3,2 \%$ dari berat total hasi? tangkapan tetapi setelah reklamasi, komposisinya berubah menjadi $13,2 \pm 1,5 \%$ dan $61,0 \pm 4,8 \%$ dari total hasil tangkapan. Nampaknya habitat ikan gabus yaitu perairan rawa yang lebih dalam jika dibandingkan dengan habitat ikan pepuyu yang relatif lebih dangkal, luasnya telah jauh berkurang karena sebagian besar lahan rawa menjadi kering. Lahan rawa yang tidak pernah lagi tergenangi sampai kedalaman 2 meter, atau paling dalam 1 meter setelah reklamasi diperkirakan merupakan salah satu penyebab menurunnya populasi ikan gabus. 
Tabel 2. Perubahan komposisi jenis ikan yang tertangkap di beje sebelum dan sesudah reklamasi lahan rawa di Kabupaten Kapuas

Table 2. Change of fish composition of "beje" fishery before and after of reclamation the swampy area in Kapuas regency

\begin{tabular}{lcc}
\hline Jenis ikan/Fish species & \multicolumn{2}{c}{$\begin{array}{c}\text { Komposisi ikan (\% berat)/ } \\
\text { (Fish composition (\% of weight)) }\end{array}$} \\
\cline { 2 - 3 } & $\begin{array}{c}\text { Sebelum reklamasi } \\
\text { (Before reclamation) }\end{array}$ & $\begin{array}{c}\text { Sesudah reklamasi/ } \\
\text { (After reclamation) }\end{array}$ \\
\hline Haruan, Channa striata & $51,5 \pm 2,6$ & $13,2 \pm 1,5$ \\
Pepuyu, Anabas testudineus & $25,6 \pm 3,2$ & $61,0 \pm 4,8$ \\
Biawan, Helostoma temminckii & $6,4 \pm 1,4$ & $4,2 \pm 1,8$ \\
Sepat, Trichogaster trichopterus & $13,1 \pm 1,8$ & $18,3 \pm 2,1$ \\
Kapar, Pristolepis fasciatus & $2,1 \pm 0,6$ & $1,8 \pm 0,6$ \\
Pentet, Clarias spp. & $1,3 \pm 0,4$ & $1,5 \pm 0,3$ \\
\hline
\end{tabular}

Rata-rata berat ikan haruan yang tertangkap mengalami penurunan dari kisaran 500-2500 g per ekor (sebelum reklamasi) menjadi 50-200 g per ekor (setelah reklamasi). Demikian pula dengan rata-rata berat ikan pepuyu dari 50-150 g per ekor (sebelum reklamasi) menjadi 25-75 g per ekor (setelah reklamasi). Penurunan ukuran ikan tersebut diduga berkaitan erat dengan rusaknya habitat ataupun penangkapan yang intensif. Seperti telah disebutkan bahwa usaha perikanan beje telah berlangsung sejak tahun 1950, penangkapan ikan dilakukan dengan cara menguras seluruh jenis ikan yang terjebak dalam beje.

\section{Alternatif Pengelolaan Sumber Daya Ikan}

Kerusakan sumber daya ikan yang diakibatkan oleh pembukaan lahan gambut di Kabupaten Kapuas, Kalimantan Tengah diperkirakan akan memakan waktu yang cukup lama dan sangat sulit untuk direhabilitasi. Oleh karena itu, upaya yang paling mendesak yang perlu dilakukan dalam rangka optimasi pemanfaatan dan pelestarian sumber daya ikan adalah mengganti usaha perikanan beje dan membangun suaka perikanan

Usaha perikanan beje dapat diganti dengan usaha budi daya ikan di kolam pasang surut atau keramba di sungai. Beje yang biasanya dibuat di tengah rawa yang jauh dari pemukiman dapat dialihkan dengan membuat beje atau kolam di sekitar pekarangan atau beje di sawah. Antara beje dengan sungai atau saluran irigasi dihubungkan dengan tatah sehingga membentuk kolam pasang surut. Keramba dapat dikembangkan di perairan sungai atau saluran irigasi.
Jenis ikan yang disarankan untuk dikembangkan adalah jenis ikan lokal seperti pepuyu atau biawan untuk di beje dan ikan baung atau ikan patin untuk di keramba di mana teknologi pembenihan ikan-ikan lokal tersebut sudah dikuasai sehingga penyediaan benihnya tidak akan menjadi masalah. Untuk pasokan benih ikan yang diperlukan dapat dilakukan dengan mengoptimalkan Balai Benih Ikan (BBI) terutama yang berada di Dadahup dan pengembangan Unit Pembenihan Rakyat (UPR). Dalam pelaksanaannya perlu didahului dengan pelatihan keterampilan pembenihan dan budi daya ikan bagi pelaksana-pelaksana intinya.

Pengembangan suaka perikanan perlu dilakukan dengan cara menetapkan beberapa perairan danau yang memenuhi kriteria dan mengembangkan cara pengelolaan bersama (co-management) seperti yang dikemukakan oleh Hartoto (2000); Hoggarth (2000); dan Kartamihardja et al.(1995). Dewasa ini di perairan umum Kabupaten Kapuas hanya terdapat satu suaka perikanan yaitu Danau Lapimping dengan luas 7,5 ha (Sarnita, 1998). Danau ini termasuk danau tapal kuda (oxbow lake) yang mendapat pasok air dari Sungai Kapuas dengan kualitas air yang cukup baik namun belum dikelola dengan baik sehingga masih termasuk kelas "Juwana" (Hartoto, 2000). Dilihat dari luas area danau dan status pengelolaannya maka keberadaan suaka tersebut belum mencukupi untuk mendukung pelestarian sumber daya perikanan perairan umum di Kabupaten Kapuas yang luasnya mencapai 524.724 ha. Oleh karena itu perlu dikembangkan suaka perikanan baru di beberapa danau kecil seperti yang terdapat di sekitar Sungai Keladan, Pelingkau, dan Sungai Garuk di desa Dadahup 


\section{KESIMPULAN}

Pembukaan lahan gambut untuk pengembangan pertanian di Kabupaten Kapuas, Kalimantan Tengah berdampak negatif terhadap penurunan produksi ikan, perubahan komposisi ikan, dan penurunan ukuran jenis ikan pada usaha perikanan beje. Produksi ikan menurun sebesar 94,6\%, komposisi jenis ikan yang dominan berubah dari ikan haruan yang semula $51,5 \pm 2,6 \%$ berat menjadi $13,2 \pm 1,5 \%$ berat dan ikan pepuyu yang semula $25,6 \pm 3,2 \%$ berat menjadi $61,0 \pm 4,8 \%$ berat. Rata-rata berat ikan haruan dan pepuyu menurun, masing-masing dari kisaran berat 500-2500 g/ekor dan 50-150 glekor menjadi 50-200 g/ekor dan 25-75 g/ekor. Perubahan tersebut terutama disebabkan oleh perubahan pola fluktuasi air karena dibangunnya saluran irigasi yang menghubungkan sungai utama sehingga habitat ikan rawa rusak di samping cara penangkapan pada usaha perikanan beje yang intensif.

Alternatif pengelolaan sumber daya ikan di sekitar lahan rawa bukaan dapat dilakukan antara lain dengan mengembangkan usaha budi daya ikan lokal (pepuyu, biawan, baung, patin), dan pengembangan suaka perikanan yang diikuti dengan penerapan pengelolaan perikanan yang berbasis masyarakat (co-management).

\section{DAFTAR PUSTAKA}

Hamid, A. 1982. Status perikanan perairan umum Kalimantan Tengah. Prosiding Seminar Perikanan Perairan Umum. Jakarta, 19-21 Agustus 1991. Buku II. Pusat Penelitian dan Pengembangan Perikanan. Hal: 123--129.

Hartoto, D.I. 2000. An overview of some limnological parameters and management status of fishery reserves in Central Kalimantan. Rep. Suwa Hydrobiol., 12: 49--74.

Hoggarth, D.D (ed.). 2000. Selection criteria \& co- management guidelines for river fishery harvest reserves. Marine Resources Assessment Group Ltd. 47 Princes Gate, London, SW7 2QA. UK. 28 hal.

Kartamihardja, E.S., W. Ismail, M. Sri Anggraeni, B. Priono \& N. Listyanto. 1995. Penelitian reservat sumber daya perikanan di Sungai Mahakam, Kalimantan Timur. Pros. Seminar Penelitian Perikanan Perairan Umum th. 1994/1995. Pros. Puslitbangkan/No.35/1995. Badan Litbang Pertanian, Puslitbang Perikanan. Jakarta.

Kartamihardja, E.S., A. Sudradjat \& S. Jocom. 1998. Identifikasi potensi pengembangan ikan air tawar di Kabupaten Kapuas dan program aksinya. Laporan Hasil Penelitian kerjasama antara BAPPEDA D.T.II Kapuas dengan Badan Litbang Depdagri. Jakarta.

Kartamihardja, E.S. 2000. Identifikasi dan karakterisasi sumber daya perikanan perairan umum di sekitar lahan rawa bukaan, Kecamatan Kapuas Murung, Kalimantan Tengah untuk pengembangan beje dan suaka produksi ikan. Pros. Seminar Hasil Penelitian Perikanan 1999/2000. Dep. Kelautan dan Perikanan, Setjen, Puslitbang Eksplorasi Laut dan Perikanan, Jakarta. Hal: 75--83.

Kottelat, M., A.J. Whitten, S.N. Kartikasari \& S Wirjoatmodjo. 1993. Freshwater fishes of western Indonesia and Sulawesi (ikan air tawar Indonesia bagian barat dan Sulawesi). Periplus Editions Ltd. Indonesia. 293 hal.

Sarnita, A.S. 1998. Pemanfaatan lahan rawa bukaan untuk pengembangan perikanan di Kalimantan Tengah. Laporan Hasil Penelitian Tahun Anggaran 1997/1998. Balai Penelitian Perikanan Air Tawar, Sukamandi

Welcomme, R.L. 1985. River fisheries. FAO Fish. Tech. Pap., (262): 330 hal. 
